\title{
Plastic surgeons: critical members of the mass casualty team
}

\author{
Mario A. Aycart, Simon G. Talbot \\ Division of Plastic Surgery, Department of Surgery, Brigham and Women's Hospital, 75 Francis Street, Boston, MA 02115, USA.
}

Correspondence to: Dr. Simon G Talbot, Division of Plastic Surgery, Department of Surgery, Brigham and Women's Hospital, Harvard Medical School 75 Francis Street, Boston, MA 02115, USA. E-mail: sgtalbot@bwh.harvard.edu

How to cite this article: Aycart MA, Talbot SG. Plastic surgeons: critical members of the mass casualty team. Plast Aesthet Res 2019;6:13. http://dx.doi.org/10.20517/2347-9264.2019.29

Received: 13 Jun 2019 Accepted: 30 Jun 2019 Published: 11 Jul 2019

Science Editor: Raúl González-García Copy Editor: Cai-Hong Wang Production Editor: Jing Yu

Keywords: Reconstructive Surgical Procedures, blast injuries, extremity reconstruction

Plastic and reconstructive surgeons are uniquely positioned to care for a variety of patients in all walks of life. We routinely take part in the multidisciplinary care that ranges from prenatal consultation for congenital abnormalities such as cleft lip and palate to nuanced reconstructive care of our aging population after tumor extirpation. This intimate involvement in the acute management and longitudinal follow-up is exemplified in traumatic extremity reconstruction.

Extremity reconstruction, like other aspects of plastic surgery, is governed by principles that allow us to tailor sophisticated solutions to challenging problems ${ }^{[1]}$. Crystal et al ${ }^{[2]}$ highlight the full spectrum of solutions using all rungs of the reconstructive ladder. To add to an already comprehensive list are two additional innovative treatment modalities particularly germane to extremity reconstruction. These are the use of "spare parts ${ }^{5[2-4]}$ and considering the possibility of future vascularized composite allotransplantation $(\mathrm{VCA})^{[5]}$. Spare parts surgery is particularly appropriate in mass casualty incidents and blast injuries, as these can cause devastating segmental loss of domain with potentially viable distal tissues. These instances may present the opportunity for innovative use of these otherwise discarded tissues or "spare parts" as heterotopic or nonanatomic replantation or rearrangement. Over two decades since the first upper extremity VCA, transplantation now factors in the planning and execution of surgical plans to preserve limb length in lieu of optimal prosthetic fit ${ }^{[6]}$. VCA has ushered new possibilities to fully restore and make whole whilst fulfilling Sir Harold Gillies' dictum of replacing like with like ${ }^{[7]}$. 
Plastic surgeons have a comprehensive reconstructive armamentarium, and it is our responsibility to think expansively and innovatively about these problems to optimize form and function while limiting donorsite morbidity. Additionally, our knowledge of long-term functional outcomes, patient satisfaction and quality of life are fundamental to our specialty and daily work. These outcomes are particularly important to the care of patients affected by severe extremity trauma. As has been previously described, factors most important to patients affected by severe lower extremity injuries include their physical capacity and functional status, pain level, and the ability to return to work, among other factors ${ }^{[8]}$. As this article and other similar collective experiences have suggested, reconstructive plastic surgeons remain a central participant in the care of complex trauma patients ${ }^{[9,10]}$.

\section{DECLARATIONS}

\section{Authors' contributions}

Writing of the manuscript: Aycart MA

Critically revised the manuscript: Talbot SG

\section{Availability of data and materials}

Not applicable.

\section{Financial support and sponsorship}

None.

\section{Conflicts of interest}

All authors declare that there are no conflicts of interest.

\section{Ethical approval and consent to participate}

Not applicable.

\section{Consent for publication}

Not applicable.

\section{Copyright}

(c) The Author(s) 2019.

\section{REFERENCES}

1. Talbot SG, Pribaz JJ. Sophisticated surgical solutions for complex wound problems. Clin Plast Surg 2012;39:325-40.

2. Crystal DT, Ibrahim AMS, Lin SJ. The role of plastic surgeons in extremity reconstruction following mass casualty incidents. Plast Aesthet Res 2019;6:1.

3. Lin CH, Webb K, Neumeister MW. Immediate tissue transplantation in upper limb trauma: spare parts reconstruction. Clin Plast Surg 2014;41:397-406.

4. Peng YP, Lahiri A. Spare-part surgery. Semin Plast Surg 2013;27:190-7.

5. Shores JT, Brandacher G, Lee WPA. Hand and upper extremity transplantation: An update of outcomes in the worldwide experience. Plast Reconstr Surg 2015;135:351e-60e.

6. Singh M, Li H, Nuutila K, Collins KC, Wall J, et al. Innovative techniques for maximizing limb salvage and function. J Burn Care Res 2017;38:e670-e677.

7. Gillies HD, Millard DR. The Principles and Art of Plastic Surgery. Boston: Little, Brown; 1957.

8. O'Toole RV, Castillo RC, Pollak AN, MacKenzie EJ, Bosse MJ, et al. Determinants of patient satisfaction after severe lower-extremity injuries. J Bone Joint Surg Am 2008;90:1206-11.

9. Kim PS, Malin E, Kirkham JC, Helliwell LA, Ibrahim AM, et al. The Boston marathon bombings: the early plastic surgery experience of one Boston hospital. Plast Reconstr Surg 2013;132:1351-63.

10. Carty MJ, Caterson EJ, Caterson SA, Chun YS, Erdmann-Sager J, et al. Why we are here: early reflections on the role of reconstructive plastic surgery in the 2013 Boston marathon bombings. Plast Reconstr Surg 2013;132:1623-7. 